\title{
Municipal solid waste management in some countries of the world
}

\author{
Olga Guman ${ }^{1}$, Olga Krinochkina ${ }^{2, *}$, Victor Khomenko², Ekaterina Wegner-Kozlova ${ }^{3,4}$ \\ ${ }^{1}$ Ural State Mining University, 30, Kuibyshev St., 620144, Yekaterinburg, Russia \\ ${ }^{2}$ Moscow State University of Civil Engineering, 26, Yaroslavskoye Shosse, 109377, Moscow, Russia \\ ${ }^{3}$ Ural Federal University named after the first President of Russia B.N. Yeltsin, 19, st. Mira, 620144, \\ Yekaterinburg, Russia \\ ${ }^{4}$ Institute of Economics at the Russian Academy of Sciences (Ural branch), 29, Moscowskaya st., \\ 620144, Yekaterinburg, Russia
}

\begin{abstract}
The aim of the study is both an analysis of existing basic solutions and innovations in the field of municipal solid waste management and new developments by domestic authors. The main research method was environmental monitoring in the impact zone of municipal solid waste (MSW) landfills. In the process of monitoring, the properties of the soils of the landfill bases were studied by testing them and further laboratory studies of lithological and mineral compositions, moisture and density, filtration and other characteristics. As a result, the following were established: the dependence of soil water permeability on particle size distribution, lithological, organ mineral compositions and the degree of their heterogeneity; maximum minimum-required thickness of screening soils at the base of MSW landfills in the Middle Urals. The established dependences of the engineering and geological characteristics of soils make it possible to use them as natural impervious screens, which can be successfully applied in other regions under similar conditions. Among the constructive solutions in the field of municipal solid waste management, the developments of domestic scientists, which were tested in the Moscow, Nizhny Novgorod and Sverdlovsk regions, are considered. Some of them relate to environmental protection in the area affected by landfills, while others are aimed at optimizing the operation of such landfills. The optimization technology consists in combining the operation and reconstruction cycles of municipal solid waste landfills within their land allotment. It allows involving previously unused materials into circulation and obtaining insulating material from "old-year" waste.
\end{abstract}

\section{Introduction}

The relevance of the research topic is undeniable, since the problem of waste management and treatment appeared simultaneously with the emergence of civilization.

Nowadays, the problem of utilization of municipal solid waste (MSW) is extremely acute. It concerns not only the health of people, but also the health of the planet as a whole.

\footnotetext{
* Corresponding author: vdovinaok@mail.ru
} 
A huge number of marine animals and birds die only because of plastic debris. Open burning of MSW leads to the release of toxic substances, an increase in cancer and other diseases, global climate change, etc.

The works of V.M. Goldberg, L.P. Gribanova, O.N. Gryaznov, R.E. Dashko, Yu.A., Israel, V.I. Osipov, Yu.E. Saet, V.T. Trofimov, V.A. Korolev, E.V. Shcherbina, A.V. Titov, N.Yu. Titova, E.A. Spitsa, O.S. Karnaukh, T.P. Volkova, as well as Cooper S.D., Latkovich V.J., Schuller R. M., Blue D.R., Zaltsberg E.A. and many other domestic and foreign scientists are devoted to various aspects of this problem.

According to the World Development Report (WDR), 2018 (UN), published by the World Bank, humanity annually produces more than 2 billion tons of MSW. Every year, 60-70 million tons are also contributed by Russians.

In 2016, the cities of the world produced 2.01 billion tons of MSW alone, which is 0.74 kilograms per person per day. [1] (Fig.1).

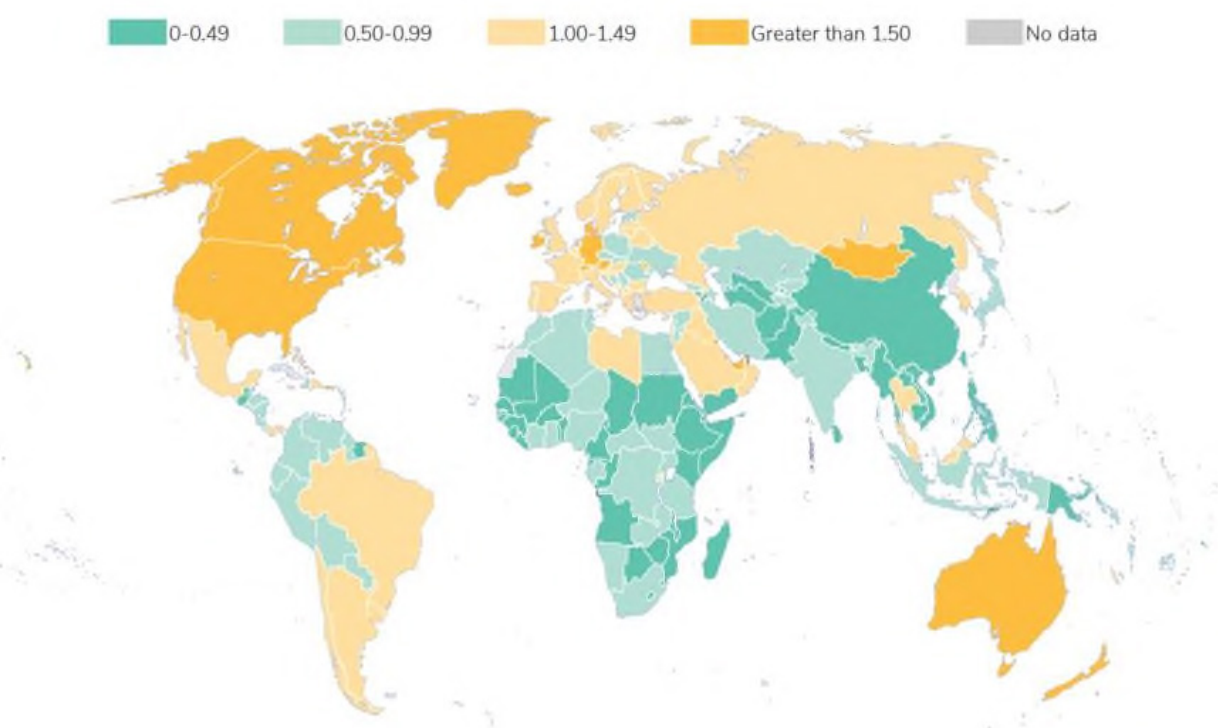

Fig. 1. Annual volume of MSW generated per capita ( $\mathrm{kg} /$ person / day).

In low-income countries, more than $90 \%$ of waste is disposed of in unregulated landfills.

One of the largest and most notorious landfills in the world is the Great Pacific garbage patch. According to various sources, its area is from 700 thousand to 15 million square kilometers. This is about $8 \%$ of the total area of the Pacific Ocean.

Bordo Poniente in Mexico City is Latin America's largest MSW landfill. Its volume is over 60 million tons. In 2010, the landfill was closed. The subsidence of the soil beneath it led to the penetration of waste decomposition products into groundwater, which became unusable.

All over the world it is forbidden to accept electronic waste for storage at MSW landfills, as they are very toxic. Nevertheless, about 200,000 tons of electronic garbage are transported to the Agbogbloshi landfill (Accra, Africa) every year, often under the guise of humanitarian aid. Now it is one of the largest landfills in the world. The World Health Organization (WHO) stipulates the inadmissibility of such practices both on the part of the countries importing such wastes, and on the part of the developing countries receiving them. The export of such waste as electronic one to landfills in developing countries 
exposes local populations involved in the informal disposal of such waste to intense negative impacts.

In recent years, countries with developed economies are switching from a linear scheme of resource consumption to the so-called circular economy. Its concept implies renewable production and consumption, subject to minimal use of resources, elimination of waste and negative impact on nature.

The land fund also belongs to the number of natural resources. Therefore, the reclamation of disturbed lands can be considered within the framework of such an economy with the circular use of products, which involves combining economic development with overcoming the ecological crisis [2]. A good example of land fund reuse in the United States of America is the reclamation of the largest municipal solid waste landfill and the establishment of Freshkills Park in its place. It is located on the west coast of Staten Island. It is one of five boroughs of New York City. Previously, all New York's waste was brought here, up to 29,000 tons of garbage per day. Since 2001, it has stopped accepting them. But garbage recycling continues now, because this is a very time consuming process. In 2012, the first section of the park was already opened. Nowadays, on this territory, instead of mountains of waste, grass fields have grown, tidal bays and salt marshes have appeared (Fig. 2) [3].

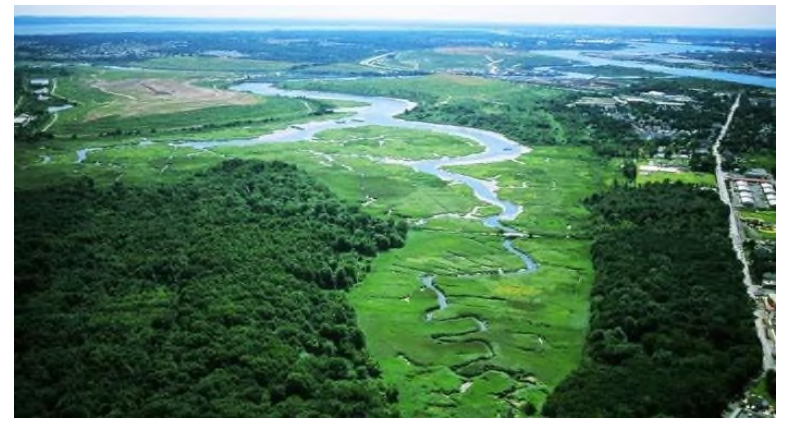

Fig. 2. Freshkills Park on the west coast of Staten Island, created after the reclamation of the largest MSW landfill in the United States of America, which has been operating since 1948.

Most of the countries of the European Union (EU) have long abandoned the storage of MSW at landfills. They are recycled and reused, and the process of their disposal does not have a negative impact on the environment. A striking example of such utilization is the well-known waste processing plant in Vienna (Fig. 3). It arose after the reconstruction of the Spittelau thermal waste treatment plant. About 250 tons of municipal solid waste is processed here every year. 


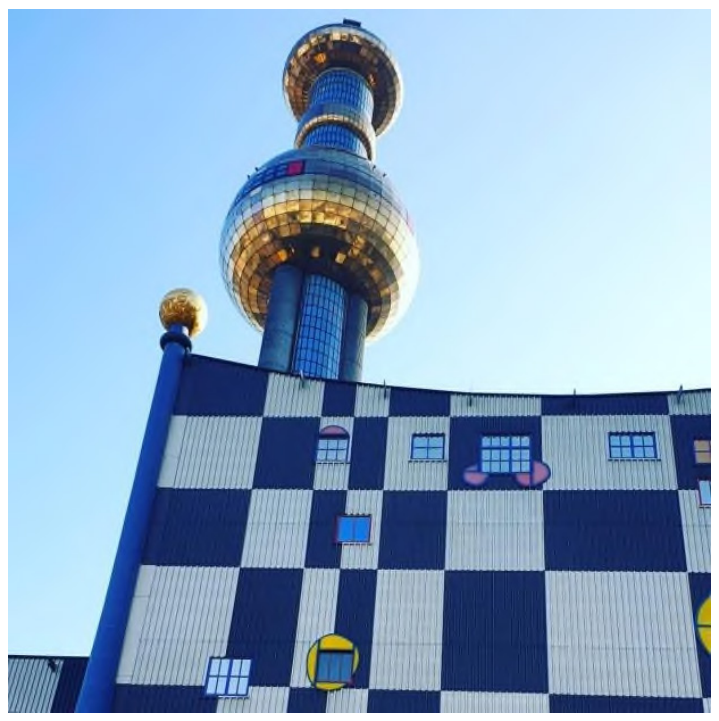

Fig. 3. Fragment of an eco-waste treatment plant in Vienna. (Author's photo).

At the same time, the generated heat is used not only in the technological process of MSW treatment, but also for heating an entire neighborhood in Vienna.

The plant uses Austrian waste treatment technology.

Thanks to the system for reducing the level of toxic substances, the plant minimized harmful emissions. They are first cleaned of dust components using a filter system, after which they pass through a special liquid, where they are freed from harmful impurities, where the gas-air mixture is cooled and saturated with water vapor. The first stage of the filter retains dust, hydrogen chloride and fluoride, heavy metal aerosols. The second stage of filtration removes sulphurous and sulfuric gases. In the last step, other impurities are precipitated. Thus, the passage of the furnace gas through the purification systems with catalysts makes it possible to almost completely eliminate many harmful chemicals from the emissions of the unique waste treatment plant in Austria [4].

But even within the EU, there are still countries that have not joined the circular economy. For example, Italy has been on the verge of garbage collapse for more than a year. The government is trying to find ways to resolve it. It is planned to cover the Malagrotta landfill with solar panels to generate electricity [5]. This is one of the largest landfills in the EU.

Other members of the European Union - Germany and Finland, on the contrary, hold a leading position in the ranking of states in terms of environmental performance index. They successfully introduce a closed-loop economy, when a significant part of recyclable materials and waste is recycled [6]. But the conditions necessary for the transition to such an economy include not only recycling, rational use of resources, use of renewable energy sources, recovery, reuse and return to production of products and their components, but also extending the life of products, the perception of products as services, sharing of products, avoiding product spoilage and changing consumption patterns. In addition, as indicated in the report of the Regional Office of the EU to the World Health Organization [7], the concept of a circular economy paves the way for sustainable development, health and decent working conditions, while respecting the environment and natural resources. Moreover, it is assumed that the transition from a linear economy (take, make, use, throw away) to a circular economy (renew, restore, share) can make a significant contribution to the achievement of the Sustainable Development Goals (SDGs). Nevertheless, the impact of the transition to a circular economy on public health is still poorly understood. In an 
effort to fill this gap, the authors of the report consider it in the context of health protection. They emphasize that such a transition may be associated with the threat of unplanned longterm negative health consequences. This concerns the risks associated with exposure to harmful components of certain recyclable materials. The authors of the report consider the threats associated with the recycling of municipal solid waste and the reuse of products as potential negative health effects. This primarily concerns the content of hazardous chemicals such as bisphenol A and brominated flame retardants in various types of materials, as well as the reuse of water and electronic waste. Until recently, the circular economy concept emphasized the benefits in terms of efficient production and consumption, while the authors of the report encourage support for research and initiatives on the impact of recycled materials on public health [8].

In Russia, almost all MSW are transported to landfills. According to the State Report [9], only $4-5 \%$ of garbage is sent for recycling. Nowadays, there are no conceptual approaches to the efficiency assessment model in the circular economy. In this regard, the organizational and economic aspects of managing the efficiency of the closed-cycle economy of an enterprise become key factors in increasing the efficiency and competitiveness of sustainable industrial development, which ensures the sustainable development of the state [10].

According to A.K. Nesterov, the use of a circular economy model in Russia will allow:

- reducing the amount of stored waste due to their processing;

- reducing the use of non-renewable resources;

- reducing the man-made load on the ecosystem;

- contributing to the creation of new jobs;

- reducing the cost of production during the modernization of production.

An algorithm for implementing the principles of a closed-cycle economy in Russia according to A.K. Nesterov is shown in table 1.

Table 1. Problems and solutions for implementing the principles of circular economy.

\begin{tabular}{|l|l|}
\hline \multicolumn{1}{|c|}{ Problems } & \multicolumn{1}{c|}{ Solutions } \\
\hline \multirow{5}{*}{$\begin{array}{l}\text { Circular economy model is not limited to } \\
\text { garbage problems }\end{array}$} & $\begin{array}{l}\text { The transition of industrial enterprises to a closed } \\
\text { water supply system, when water does not leave } \\
\text { the production circuit of the enterprise, it is } \\
\text { purified and reused at the same enterprise }\end{array}$ \\
\cline { 2 - 3 } Lack of target orientation in manufacturing & $\begin{array}{l}\text { Implementation of producer responsibility for the } \\
\text { processing of their "old" goods } \\
\text { Using the "recycling fee" model }\end{array}$ \\
\hline \multirow{5}{*}{ enterprises } & $\begin{array}{l}\text { Financial incentives for the introduction of new } \\
\text { technologies }\end{array}$ \\
\cline { 2 - 3 } Separate waste collection system \\
\cline { 2 - 3 } Waste recycling is not scaled down & $\begin{array}{l}\text { Intensification of increasing the depth of product } \\
\text { processing in order to reduce its cost } \\
\text { Multiple production of a product from the same } \\
\text { set of resources }\end{array}$ \\
\hline & $\begin{array}{l}\text { Development and implementation of recycling } \\
\text { technologies }\end{array}$ \\
\cline { 2 - 3 } & $\begin{array}{l}\text { Involving society, business and scientists to } \\
\text { solving waste recycling problems }\end{array}$ \\
\hline
\end{tabular}

According to the same author, the main tasks of the transition to a circular economy in Russia are: increasing the level of reuse of municipal waste up to $70 \%$; increasing the level of packaging reuse up to $80 \%$; a ban on the disposal of any recyclable and biodegradable waste at landfills. 
But even the creation of the appropriate industries (collection, sorting, transportation and processing of waste) is not a guarantee of the implementation of the above tasks - there is a need for a change in the way of thinking [11].

The Government of the Russian Federation sets the task to abandon landfills as disposal areas for MSW and by 2030 prohibit the placement of unprocessed waste there. With the entry into force on 01.01 .19 of the document "On Amendments to the Federal Law "On Production and Consumption Wastes" dated 31.12.17, there was hope for the country's transition to a new system for the management of MSW and waste in general.

According to leading economists, the key conditions for the introduction of a circular economy into the Russian industry are the use of an environmental management system focused on accounting for production and consumption waste, government support for environmental initiatives and scientific research in this area, the mandatory participation of the consumer in ensuring the recycling of the production process. This requires structural modernization of the entire industry and its transfer to a new, modern level of functioning and further development [12].

\section{Materials and methods}

In this paper, authors' data on thematic works carried out by them by order of the Ministry of Natural Resources of the Moscow and Sverdlovsk Regions were used. Experimental studies were carried out in the field and laboratory conditions. Among the field methods, the main one was environmental monitoring in the zone of impact of municipal solid waste (MSW) landfills. In the process of monitoring, their effect on the environment and soil properties of the polygon bases was studied by testing them and further laboratory studies of lithological and mineral compositions, moisture and density, filtration and other characteristics. In this case, the following research methods were used: sieve and sludge analysis to determine and clarify the material composition of rocks, to determine moisture content - the method of drying to constant mass (thermometric method), density - the cutting ring method, filtration coefficient - using the Nesterov-Boldyrev method. All of the above methods for obtaining engineering and geological parameters of soils comply with modern national standards (Interstate standard - GOST5180-2015. Soils. Methods for laboratory determination of physical characteristics). The methods of analogy, synthesis and analysis of the obtained and available materials were also used.

\section{Results and discussion}

There is a lot of research and innovation in the field of MSW management in Russia. Let's consider some of them using the example of the Sverdlovsk and Nizhny Novgorod regions.

In the Middle Urals, in the Sverdlovsk Region, extensive field and laboratory studies of MSW landfills were carried out. As a result, it was found that their natural bases, due to their lithological composition and other features, with sufficient thickness, can be used as natural anti-filter screens [6]. The results of the studies in a generalized form are given in tables 2 and 3 .

Table 2. Filtration properties of the soil of MSW landfill bases in the Sverdlovsk region.

\begin{tabular}{|l|l|l|l|}
\hline $\begin{array}{c}\text { Water } \\
\text { permeability }\end{array}$ & $\begin{array}{c}\text { Kf value intervals } \\
(\mathbf{m} / \text { day })\end{array}$ & \multicolumn{1}{c|}{$\begin{array}{c}\text { Lithological } \\
\text { composition of soils }\end{array}$} & \multicolumn{1}{c|}{$\begin{array}{c}\text { Examples of MSW } \\
\text { landfills }\end{array}$} \\
\hline High & $>1.0$ & $\begin{array}{l}\text { Crushed stone, sands, } \\
\text { sandy loam, crushed } \\
\text { stony loam. }\end{array}$ & $\begin{array}{l}\text { Irbit, } \\
\text { Yekaterinburg, } \\
\text { Shirkorechensky } \\
\text { landfill }\end{array}$ \\
\hline
\end{tabular}




\begin{tabular}{|c|c|c|c|}
\hline Average & $1-0.01$ & $\begin{array}{l}\text { Crushed stony soil, sandy } \\
\text { loam, crushed stony } \\
\text { loam, clay with coarse } \\
\text { clastic inclusions. }\end{array}$ & $\begin{array}{l}\text { Mikhailovsky, } \\
\text { Yekaterinburg, } \\
\text { Shirkorechensky } \\
\text { landfill, } \\
\text { V. Salda }\end{array}$ \\
\hline Low & $<0.01$ & $\begin{array}{l}\text { Loams, loams with } \\
\text { interlayers of clay, clay }\end{array}$ & $\begin{array}{l}\text { Irbit, } \\
\text { Yekaterinburg, } \\
\text { Gornoshchitsky } \\
\text { landfill, } \\
\text { B. Sedelnikovo, } \\
\text { V. Salda, } \\
\text { Kachkanar }\end{array}$ \\
\hline
\end{tabular}

Table 2 shows the dependence of the values of the filtration coefficient (Kf) on the lithological composition of the soils at the bases, but it is not quite direct. There is a group of soils with a very wide range of fluctuations in values of the filtration coefficient. This is typical for soils with a heterogeneous lithological composition. For example, in weathered andesite-basalts at the base of the Kachkanar landfill, Kf values range from 0.06 to 0.12 $\mathrm{m} /$ day, in deluvial loams at the base of the Salda polygon - from 0.001 to 0.33 , etc.

In addition, a wide range of fluctuations in filtration coefficient values is often observed with different compaction of base soils, in particular: friable sands have filtration coefficient values from 2.3 to $34.9 \mathrm{~m} /$ day, and in a compacted state, this coefficient is from 1.8 to $25.0 \mathrm{~m} /$ day. It was also established that compaction of some genetic types of clay rocks in the range of "optimal humidity" also leads to a decrease in the filtration coefficient, sometimes by several orders of magnitude.

As a result of studies carried out at landfills of solid municipal waste and in the zones of their influence, the minimum required thickness of the soils of their bases for screening pollution was established [14]. This became possible due to the study of the lithological composition of soils, the study of their sorption properties, the degree of their heterogeneity, as well as the structural position of the strata underlying the polygons.

Table 3. The minimum required soil thickness of the base of MSW landfills for screening pollution.

\begin{tabular}{|c|c|c|}
\hline $\begin{array}{c}\text { Lithological composition } \\
\text { of soils }\end{array}$ & $\begin{array}{c}\text { Minimum base thickness } \\
\text { of landfills (m) }\end{array}$ & Examples of MSW landfills \\
\hline $\begin{array}{c}\text { Clays, loams with } \\
\text { interbeds of clay, peat }\end{array}$ & $2-4$ & $\begin{array}{c}\text { Irbit, Mikhailovo, } \\
\text { Nizhny Tagil, } \\
\text { B. Sedelnikovo }\end{array}$ \\
\hline Loam & $4-5$ & $\begin{array}{c}\text { Ibrit, V. Salda, } \\
\text { Yekaterinburg, } \\
\text { Gornoshchitsky III landfill, } \\
\text { Shirkorechensky landfill, } \\
\text { B. Sedelnikovo, } \\
\text { Kachkanar }\end{array}$ \\
& & $\begin{array}{c}\text { Kachkanar, } \\
\text { Yekaterinburg, }\end{array}$ \\
Crushed stony loams, & $5-7$ & $\begin{array}{c}\text { Shirkorechensky landfill, } \\
\text { Aramil }\end{array}$ \\
\hline sandy loam & &
\end{tabular}

As follows from the table 3, the thickness of the soils of the MSW landfill bases as natural screens directly depends on their lithological composition, their heterogeneity, and the presence of organic inclusions.

It should also be noted that in the Sverdlovsk region, with the participation of the authors, a typification of MSW landfills of the Middle Urals was carried out taking into account their geological conditions, scales and criteria for assessing their environmental 
safety [15]. The classification methodology was based on the following principles: hierarchical approach; the significance of the estimates; objectivity of information.

The hierarchical approach provides for the comparison of commensurate units when using the method of analogies, therefore the calculation of the degree of potential hazard of landfills to the environment is carried out in points.

The significance of the estimates was achieved using only those classification features that can have a significant impact on the environment during the operation of landfills for solid municipal waste and industrial waste (IW). For example, the area of landfills and the volume of stored waste are undoubtedly significant and, perhaps, the most important factor of influence on the environment. An equally important factor is control over the environmental impact in the area affected by landfills and the way of accumulating waste. All of the above factors are anthropogenic, and therefore, if considered in the risk model, are manageable [16].

The objectivity of the information was achieved by the fact that the number of assessment factors (classification signs) was necessary and sufficient, as well as confirmed by a significant amount of data obtained from the results of field and laboratory studies.

An example of the classification of landfills for MSW by the degree of their hazard to the environment for a particular region is given in table 4 . In it, classification signs by value were differentiated into 3 groups, each of which was assigned a certain number of points (from 1 to 3 ) depending on the degree of their potential danger. Thus, the minimum score of the potential environmental hazard of the functioning of landfills is one point and is assigned to the lowest value of the parameter, and a score of three points is assigned to the maximum.

A rather narrow interval (from 1 to 3 ) of scores was a condition for limiting the number of factors used, since with an increase in their number, the significance of each individual factor in the total score decreases, and with a sufficiently large number of them, additive scores are leveled [17]. For the same reason, it was decided to limit the number of factors (features) to 7. With this approach, the weight of each of the classification features in its group significantly affects the total score of the corresponding block and the integral assessment of the object as a whole [18].

Table 4. Classification of landfills for solid municipal and industrial waste in the Sverdlovsk region according to the degree of their hazard based on scores.

\begin{tabular}{|c|c|c|c|}
\hline \multirow{2}{*}{ Classification features } & \multicolumn{3}{|c|}{ Scores } \\
\hline & 1 & 2 & 3 \\
\hline $\begin{array}{l}\text { Landfill area and waste } \\
\text { volume }\end{array}$ & $\begin{array}{l}\text { Small }(0.3-4.0 \text { ha; }< \\
\left.100000 \mathrm{~m}^{3}\right)\end{array}$ & $\begin{array}{l}\text { Medium }(4.0-10 \text { ha; } \\
\left.\mathrm{n} \cdot 100000 \mathrm{~m}^{3}\right)\end{array}$ & $\begin{array}{l}\text { Large }(10-65 \text { ha; } n \\
\left.\cdot 1000000 \mathrm{~m}^{3}\right)\end{array}$ \\
\hline $\begin{array}{l}\text { Composition of stored } \\
\text { waste }\end{array}$ & Municipal solid waste & $\begin{array}{l}\text { Municipal solid waste } \\
+ \text { industrial waste } \\
(\mathrm{IW}<30 \%)\end{array}$ & $\begin{array}{l}\text { Municipal solid } \\
\text { waste }+ \text { industrial } \\
\text { waste } \\
(\mathrm{IW}>30 \%)\end{array}$ \\
\hline $\begin{array}{l}\text { Environmental impact } \\
\text { control }\end{array}$ & Controlled & Partly controlled & Uncontrolled \\
\hline Accumulation method & Trench & Combined & In bulk on the relief \\
\hline $\begin{array}{l}\text { Engineering and } \\
\text { geological } \\
\text { characteristics of the } \\
\text { underlying rocks of the } \\
\text { base }\end{array}$ & $\begin{array}{l}\text { Clay rocks } \\
\text { Rock, monolithic } \\
\text { soils }\end{array}$ & Fractured rocky soils & $\begin{array}{l}\text { Sandy, } \quad \text { Large } \\
\text { clastic, }\end{array}$ \\
\hline $\begin{array}{l}\text { Position in neotectonic } \\
\text { structures }\end{array}$ & $\begin{array}{l}\text { Meso-Cenozoic } \\
\text { platform cover of the } \\
\text { Trans-Urals }\end{array}$ & Cis-Ural foredeep & $\begin{array}{l}\text { Orogenic structures } \\
\text { of the Urals }\end{array}$ \\
\hline Water regime of the & Nonleaching & Partially leaching & Leaching \\
\hline
\end{tabular}




\begin{tabular}{|l|l|l|l|}
\hline $\begin{array}{l}\text { geotechnical system } \\
\text { "landfill - geological } \\
\text { environment" }\end{array}$ & & \\
\hline $\begin{array}{l}\text { Danger level* } \\
\text { (sum of points) }\end{array}$ & Low (7-10) & Medium (11-17) & High (18-21) \\
\hline
\end{tabular}

*The gradation of the degree of danger was carried out on the basis of statistical data (selection of modal values of the observation series). The accepted estimation interval covers the main category of the manifested classification features.

The above classification was carried out on the basis of a long series of observations in the monitoring mode at municipal solid and industrial waste landfills, using field and laboratory studies, as well as taking into account the data of neotectonic zoning $[19 ; 20]$ and other literary sources [21].

It is necessary to clarify the role of natural factors (signs) in the geotechnical system "landfill - geological environment" of the above classification. These include: the position of landfills in neotectonic structures, engineering and geological characteristics of the underlying rocks and the hydrogeological regime of the base. These factors cannot be controlled, but they must be taken into account in the operation and, first of all, in the design of landfills for municipal solid waste.

The position of landfills in neotectonic structures must be taken into account, since it, albeit indirectly, affects the permeability of the earth's crust, its mobility, as well as the manifestation of inherited tectonic paleostructures in the modern relief. It (the position of the landfills) can be established by the zoning method using neotectonic maps, which reflect the integral picture of deformations of the latest stage of tectogenesis.

The Meso-Cenozoic platform cover of the Trans-Urals is a flat, mainly platform singletier territories composed mainly of blanket sedimentary deposits. In geomorphological terms, they are stratal-accumulative and accumulative plains created mainly by negative neotectonic movements that have experienced the latest deformations. These territories are overlain by allochthonous Quaternary deposits of predominantly glacial series (glacial and fluvioglacial deposits). They are characterized by low-activity surface runoff. All of the above factors are natural prerequisites for the safest functioning of landfills for municipal solid and industrial waste.

The Cis-Ural foredeep is the marginal ledge of the folded base of the East European Platform with a predominance of the newest arched and block uplifts. The total amplitude of neotectonic movements here reaches $500 \mathrm{~m}$ and more. The Cis-Ural foredeep and the adjacent regions of the platform plate are characterized by intensive development of permeability zones. There is a clear connection between the permeability zones and movements along the latest tectonic structures. The most active ones are permeability zones limited to the boundaries of the junction of neotectonic structures of different ranks. The development of permeability zones within neotectonic sub-provinces is indicated by the presence of paths (channels) for the migration of solutions and gases, which confirms their internal tectonic disturbance. For permeability zones, the most characteristic are: linearity, relatively small thickness of the overburden, manifestation of dangerous geological processes, such as suffusion, landslides, etc.

All this: the high permeability of the earth's crust, movements along the latest tectonic structures, the development of hazardous geological processes (HGP) in conjunction with a rather dissected topography (intensive surface runoff, activation of HGP) cause very unfavorable conditions for the functioning of MSW landfills within this neotectonic structure.

Orogenic structures of the Urals, in general, are even more permeable and active in neotectonic terms than the structures of the Cis-Ural foredeep. They are characterized by widespread suture faults, pronounced thick crushing zones. For example, as a result of 
neotectonic movements, the zone of the Krasnoufimsk fault of Precambrian origin poses a danger of tectonic and exogenous processes development within its limits. In general, the Ural folded region is characterized by a high dissection of the relief, which contributes to the intensity of surface runoff, and the high permeability of structures due to renewed or revived recent movements and susceptibility to folded deformations determine the possibility of hazardous geological processes, both exogenous and endogenous, including those activated in the result of technogenesis.

Engineering and geological characteristics of the underlying rocks of the base is one of the most important natural factors of the influence of municipal solid and industrial waste landfills on the environment. The protection of groundwater depends on them. Despite the fact that when creating MSW landfills, their foundations are equipped with a protective shield, the presence of rocks with waterproof properties at the base of landfills creates reliable protection for the groundwater horizons and for the entire complex of groundwaters as a whole, because the fact of migration of pollutants through the "hydraulic windows" from one aquifer to another is widely known. In addition, as shown above, some rocks at a certain thickness, lying at the base of MSW landfills, have such engineering and geological parameters (characteristics) that they can be used as natural impervious screens.

To clarify these characteristics of the underlying rocks of the base of the landfills, a study of their lithological and mineral compositions was carried out, the moisture and density of soils, as well as their filtration properties, were determined. The latter were determined both in the field and in the laboratory. It should be noted the close relationship and interdependence of the physical-mechanical and water-physical properties of rocks. The study of the water - rocks system should be approached in a complex manner, and it should be considered together with its quantitative assessment of aquifers as a single natural system, the properties and behavior of which are determined by the interaction and ratio of its constituent phases [22]. And it was in the complex that the underlying rocks of the base of the landfills were studied to obtain such characteristics as lithological and mineral composition, moisture and density, as well as their permeability. These characteristics of the underlying soils, as shown above (Tables 2,3), directly affect the safety of functioning of municipal solid waste landfills, and under certain conditions they can be a confirmation of the possibility of using soils as natural impervious screens.

The water regime of the geotechnical system "landfill - geological environment" was determined on the basis of a number of hydrological observations and other data of the hydrometeorological service in the zone of influence of landfills of municipal solid and industrial waste. This mode is determined by the position of the landfill in the landscape. The leaching type of water regime is found mainly in areas where the average annual precipitation exceeds the average annual evaporation. In this regime, the annual (one- or multiple) through-thickness wetting of the soil-ground layer to groundwater is characteristic (mainly in spring, during snowmelt). Periodically, the leaching type is found in the foreststeppe zone on gray forest soils, podzolized and leached chernozems. The soil is leached periodically. The non-leaching type of water regime is widespread where the average annual precipitation is significantly less than the average annual evaporation. The MSW landfills of the Sverdlovsk region are located in different landscape conditions.

The data of the consolidated classification of municipal solid waste landfills suggests that it is advisable to carry out comprehensive environmental monitoring at medium and large landfills, as it was done in the Middle Urals. For forecasts of environmental pollution at small landfills (less than 0.3-4.0 hectares), it is enough to use methods of analogies and expert assessments, which are based, as a rule, on the typological zoning of the geological environment, as well as on the typological classification of municipal solid waste landfills. It is necessary to clarify that integrated monitoring should begin at the stage of their design (study of background characteristics in the area of the proposed construction of landfills, 
forecasting their impact on the environment, etc.) and end after the elimination and reclamation of landfills to assess the degree of restoration of environmental components and the possibility of using disturbed lands in the future. Similar work on environmental monitoring in the zone of influence of landfills at various stages of its functioning was carried out by the authors in the Moscow region [23; 24].

In the Nizhny Novgorod region, the studies dealt with another aspect of MSW management. There, the technology for combining the reconstruction and operation of landfills was tested at the landfill [25-29]. It consists in the allocation and isolation of a small area in the body of the landfill and the separation of deposited waste on it. By screening method, they were divided into topsize and undersize. The first ones were sent for processing, the second ones were sanitized with a specific sorbent and, subsequently, were used as an insulating material. Then, this site, having freed, was again used for MSW, thereby not requiring additional land acquisition. All this made it possible to optimize the environmental management of the MSW disposal area by obtaining additional materials from the waste and reusing the site itself, which, of course, minimized their impact on the environment. A similar pilot project was carried out at the "old-year" waste landfill and in the city of Pervouralsk, Sverdlovsk region.

\section{Conclusions}

- A review and analysis of the problems in the field of MSW disposal in the world was carried out, and some ways of their solution were considered. The problems of the transition of Russian industry to a circular economy are considered, and proposals of domestic scientists for its implementation in the near future are presented.

- Using the example of the developments of domestic scientists tested in the Sverdlovsk and Moscow regions, some approaches to solving problems in the field of environmental protection in the impact zone of MSW landfills are shown.

- The results of field and laboratory studies are presented that can optimize the design of MSW landfills using the natural ability to screen pollution by soils of the bases of these landfills under certain conditions. The dependence of the permeability of soils on the granulometric, lithological, organomineral compositions and the degree of their heterogeneity has been established. The limiting minimum required thickness of the shielding soils of the foundation of MSW landfills for the Middle Urals has been determined. These engineering and geological characteristics of soils make it possible to use them as natural impervious screens, which is applicable in other regions in similar natural conditions.

- The typification of municipal solid and industrial waste landfills was carried out according to the degree of their hazard based on point assessments. The most significant ones, including anthropogenic factors (signs), were selected as classification signs: landfill area and volume of waste; the composition of the stored waste; control over the impact of the landfill on the environment; method of accumulation and natural, engineering and geological characteristics of the underlying rocks of the base of landfills, the position of landfills in neotectonic structures; water regime of the geotechnical system "landfill geological environment".

- The technology of combining the cycles of reconstruction and operation of municipal solid waste landfills was considered. The proposed technology allows: extracting early unused materials, obtaining insulation material from deposited waste, and then reusing the MSW disposal area without expanding the boundaries of the landfill itself, thereby minimizing its overall impact on the environment. The presented technology was tested in the Moscow, Nizhny Novgorod and Sverdlovsk regions. 


\section{References}

1. World Bank Report. About sustainable development goals. World development report (New York, 2018)

2. E.O. Wegner-Kozlova, O.M. Guman, Proceedings of universities. Mining journal 4, 61-66 (2015)

3. K. Field, Freshkills: how to turn a landfill into a city park https://go.mail.ru/redir?type=sr\&redir=eJwNyDEOwjAMAMB8htENqKiiPIQ9CqGJH OTIdqPyCN7AiphZOvIYBiQmBma48aJqka21jn0UqkGbo2DD4z80RwsKZTAlQaCnLyzBw4SMeUsgA6hcKjsNCIIdRlHqDAQ016QTlAcozGrbrnu7ZrN-Y9Xe-

Pxe3yPe9en_k5_wDdsDJ1\&src=39ddd0c\&via_page=1\&user_type=5a\&oqid=ea3c394 053b5e08e

4. D.A. Chasovskaya, A.A. Bocharova, Materials of the LIV Student Scientific and Practical Conference dedicated to the 75th anniversary of Victory in the Great Patriotic War (FSBEI HE SAU of Northern Trans-Urals, Tyumen, 2020)

5. Methods for estimating greenhouse gas emission from municipal waste disposal (EIIP: ISF Consulting, 1999)

6. V.S. Tsirenshchikov, New industrial strategy of the European Union. European Union: facts and comments 100, 43-49 (2020) DOI: 10.1521/eufacts220204349

7. Circular economy and health: opportunities and risks (2019) ISBN 9789289054300

8. A New Industrial Strategy for Europe. Communication from the commission to the European parliament, the European council, the council, the European economic and social committee and the committee of the regions (European commission, Brussels) 10.3.2020.com.2020/ n 102 final

9. State report "On the State and Environmental Protection of the Russian Federation in 2017”. Ministry of Natural Resources of Russia, documents, state reports "On the state of the environment" (Russian Federation, 2018)

10. V.A. Koshkarova, Innovations and investments 6, 105-109 (2020) ISSN: 2307-180X

11. A. Mottaeva, A. Ivashchenko, A. Ryattel, E3S Web of Conferences 164, 10038 (2020) https://doi.org/10.1051/e3sconf /202016410038

12. N.Yu. Titova, Vestnik of the Vladivostok State University of Economics and Service 12(2), 29-37 (2020)

13. O.M. Guman et al., Ecological and geological conditions and environmental monitoring of landfills for municipal solid waste in the Middle Urals, Monograph ("UIPC" LLC, Yekaterinburg, 2013)

14. O.M. Guman, N.N. Nechaeva, Technogenesis and Ecology. Information and thematic collection (Yekaterinburg, 2002)

15. O.M. Guman, Notes of the Mining Institute, Problems of modern engineering geology. St. Petersburg 153, 58-60 (2003)

16. O. Krinochkina, E3S Web of Conferences. Innovative Technologies in Environmental Science and Education, ITESE 2019, 01050 (2019)

17. O.K. Krinochkina, Subsoil use in the XXI century 6(69), 134-143 (2017) ISSN No. 1998-4685

18. L.A. Krinochkin, A.A. Golovin, N.G. Gulyaeva, N.Ya. Trefilova, Exploration and protection of mineral resources 11, 8-15 (2004)

19. K.K. Zoloev, D.A. Dodin, V.A. Koroteev, S.A. Rylkov, N.M. Chernyshov, Lithosphere 6, 3-14 (2007) 
20. N.I. Korchuganova, The latest tectonics with the foundations of modern geodynamics (Geokart, GEOS, M., 2008)

21. E.A. Spitca, O.S. Karnaukh, T.P. Volkova, Environmental safety assessment criteria for municipal solid waste landfills (Don NTU, Donetsk, 2006)

22. N. Tulebayeva, D. Yergobek, G. Pestunova, A. Mottaeva, Z. Sapakova, E3S Web of Conferences 159, 01012 (2020) https://doi.org/10.1051/e3sconf/202015901012

23. A.V. Titov, Environmental management 1, 106-109 (2018) ISSN No. 1997-7-6011

24. L.P. Gribanova, O.K. Vdovina, R.V. Vysokinskaya, Ecological problems of industrial regions. Materials of the conference "URALECOLOGY Technogen-2003" (Yekaterinburg, 2003)

25. R.V. Vysokinskaya, O.K. Krinochkina, Solid waste management in developed and developing countries. Geoecology, engineering geology, hydrogeology, geocryology (RAS, M., 2020) ISSN: 0869-7809

26. Vatin, N.I., Chechevichkin, V.N., Chechevichkin, A.V., Shilova, Y., Yakunin, L.A. Application of natural zeolites for aquatic and air medium purification. Applied Mechanics and Materials. 2014. 587-589. Pp. 565-572.

DOI:10.4028/www.scientific.net/AMM.587-589.565.

27. Vatin, N.I., Chechevichkin, V.N., Chechevichkin, A.V., Shilova, Y.S. Possible applications of clinoptilolites for natural water purification. Magazine of Civil Engineering. 2013. 37(2). DOI:10.5862/MCE.37.12.

28. G. Semenova, E3S Web of Conferences 138, 02012 (2019) https://doi.org/10.1051/e3sconf/201913802012

29. G. Semenova, E3S Web of Conferences 157, 02023 https://doi.org/10.1051/e3sconf/202015702023

30. L. Pushkareva, M. Pushkarev E3S Web of Conferences 164, 10027 (2020) doi:10.1051/e3sconf/202016410027 